\title{
Aspek Hukum Transaksi Jual Beli Rumah Susun/Apartemen di Daerah Istimewa Yogyakarta Kaitannya dengan Peran Notaris-PPAT
}

\author{
Pandam Nurwulan \\ Fakultas Hukum Universitas Islam Indonesia \\ Jl. Taman Siswa No.158. Yogyakarta \\ nnurwulan@gmail.com
}

\begin{abstract}
This research discusses, first, whether there has been any regulatory compliance related to purchase and sale transactions of Flats/Apartments in Special Region of Yogyakarta? Second, how is the role of Land Title Registrar in such legal relationship? This was a normative legal research whose data analysis was descriptive qualitative. The conclusions are: first, there has not been any Local Regulation regarding Flats/Apartments until the present time so that Regent/Mayor Regulations (Mayor Regulation Number 7 of 2015 regarding the Certificate of Proper Function of Flat, Mayor Regulation Number 8 of 2015 regarding the Legalization of Title of Flat Separation, Mayor Regulation Number 9 of 2015 regarding the Union of Owners and Occupants of Flats and Regent Regulation of Sleman Number 40 of 2015 regarding the Legalization of Report and Title of Flat Separation are still in the form of a guideline which should have become an implementation regulation from the Local Regulation regarding purchase and sale transactions of Flats/Apartments. Second, Land Title Registrars should play their roles professionally by mastering all regulations related to Flats/Apartments so that any land titles they issue related to purchase and sale transactions of Flats/Apartments will have authenticity as a proof.
\end{abstract}

Keywords: purchase and sale transaction, flat/apartment, roles of land title registrar

\begin{abstract}
Abstrak
Penelitian ini mengkaji, pertama, apakah sudah ada kesesuaian regulasi mengenai transaksi jual beli Rumah Susun/Apartemen di Daerah Istimewa Yogyakarta? Kedua, bagaimana peran Notaris-PPAT dalam hubungan hukum tersebut. Metode penelitian yang digunakan adalah penelitian hukum normatif dengan pengolahan dan analisa data secara deskriptif kualitatif. Dari penelitian ini disimpulkan bahwa: pertama, Peraturan Daerah mengenai Rumah Susun/Apartemen di Daerah Istimewa Yogyakarta belum ada sampai saat ini sehingga Peraturan Walikota/Bupati (Peraturan Wali Kota Nomor 7 tahun 2015 tentang Sertifikat Laik Fungsi Rumah Susun, Peraturan Wali Kota Nomor 8 tahun 2015 tentang Pengesahan Akta Pemisahan Rumah Susun, Peraturan Wali Kota Nomor 9 tahun 2015 tentang Perhimpunan Pemilik dan Penghuni Satuan Rumah Susun dan Peraturan Bupati Sleman Nomor 40 Tahun 2015 tentang Pengesahan Pertelaan dan Akta Pemisahan Rumah Susun) masih berupa pedoman yang seharusnya merupakan peraturan pelaksanaan dari Peraturan Daerah tentang transaksi jual beli Rumah Susun/Apartemen. Kedua, bahwa seharusnya Notaris-PPAT mengambil peran secara profesional dengan menguasai semua dan segala regulasi mengenai Rumah Susun/Apartemen sehingga akta-akta yang dibuatnya berkenaan dengan transaksi jual beli Rumah Susun/Apartemen itu akan mempunyai otentisitas yang sempurna sebagai alat bukti.
\end{abstract}

Kata Kunci : Transaksi jual beli, rumah susun/apartemen, peran Notaris-PPAT 


\section{Pendahuluan}

Perumahan merupakan kebutuhan dasar di samping sandang dan pangan, oleh karenanya untukmemenuhi kebutuhan akan perumahanyang meningkat bersamaan dengan pertambahan penduduk diperlukan penanganan dan perencanaan yang seksama dan disertai keikutsertaan dana dan daya yang ada dalam masyarakat. Pada dasarnya pembangunan perumahan merupakan tanggungjawab dari masyarakat untuk mencapai tujuan tersebut, serta menciptakan suatu iklim yang memadai bagi usaha swasta di bidang perumahan. Dengan meningkatnya potensi usaha swasta serta peningkatan dana dan daya masyarakat maka partisipasi masyarakat akan berdaya guna dan berhasil guna. ${ }^{1}$ Di Daerah Istimewa Yogyakarta saat ini tumbuh dan bermunculan bangunan hunian bertingkat yang saat ini masyarakat lebih familiar menyebutnya dengan Apartemen atau Condotel (Condominium dan Hotel), dengan berbagai fasilitas yang ada dalam bangunan bertingkat tersebut. Dengan berkembangnya potensi bisnis properti di Daerah Istimewa Yogyakarta, maka para pengembangpun di dalam promosinya kepada masyarakat menggunakan istilah bangunan bertingkat dengan Apartemen, Condotel ataupun Apartel yang barangkali untuk menaikan nilai jual propertinya. Apapun istilah untuk bangunan bertingkat dimaksud jika berdasarkan peraturan perundang-undangan di negara kita (Undang-Undang Nomor 20 Tahun 2011 tentang Rumah Susun Pasal 1 (1), UU 1 Tahun 2011 tentang Perumahan dan Kawasan Pemukiman, dan Permendagri 32 Tahun 2010 tentang Pemberian Izin Mendirikan Bangunan, untuk bangunan bertingkat disebut “Rumah Susun”), apakah Rumah Susun Umum, Khusus ataupun Rumah Susun Komersial, jadi Apartemen dalam hal ini merupakan Rumah Susun Komersial yang oleh pengembang diselenggarakan untuk mendapatkan keuntungan bisnisnya.

Peneliti berpendapat bahwa bermunculannya Apartemen/Rusun di Daerah Istimewa Yogyakarta terjadi karena banyaknya investor yang menjalankan aktiftas bisnis real properti saat ini dan yang akan datang yang tentu

1 C. Djemabut Blaang, Perumahan dan Pemukiman Sebagai Kebutuhan Dasar, Yayasan Obor Indonesia, Jakarta, 1986, hlm. 3-4. 
saja hal ini akan berpengaruh terhadap perilaku konsumen/pembeli properti dimaksud. Meskipun kegiatan di bidang Rusun/ Apartemen ini dapat dijadikan indikator seberapa aktifnya kegiatan ekonomi secara umum yang sedang berlangsung, namun perkembangan industri Rusun/Apartemen perlu dicermati secara hati-hati karena dapat memberikan dampak pada dua sisi yang berbeda, yakni dapat menjadi pendorong bagi kegiatan ekonomi dan naiknya berbagai kegiatan disektor lain yang terkait. ${ }^{2}$

Di Yogyakarta, transaksi jual beli satuan rumah susun yang belum selesai dibangun semakin meningkat (berdasarkan pra penelitian yang dilakukan peneliti, dilihat dengan mulai banyaknya penawaran via pameran di mall-mall di Yogyakarta), bahkan tidak jarang jual beli satuan rumah susun ini dilakukan pada saat rumah susun masih berada dalam perencanaan. Pelaksanaan jual beli satuan rumah susun yang seperti itu dilakukan dengan cara memesan terlebih dahulu atas unit yang akan dibeli, yang kemudian dituangkan dalam perikatan pendahuluan atau perikatan jual beli atau yang lebih dikenal dengan sebutan perjanjian perikatan jual beli ("PPJB"). Dengan tujuan untuk mengamankan kepentingan penjual (perusahaan pembangunan perumahan dan permukiman) /"Pengembang" dan calon pembeli satuan rumah susun/“Pemesan", maka dirasakan perlunya pengaturan secara khusus mengenai pedoman perikatan jual beli satuan rumah susun. Pedoman dimaksud sudah dituangkan dalam Keputusan Menteri Negara Perumahan Rakyat Republik Indonesia Nomor 11/KPTS/1994 tahun 1994 tentang Pedoman Perikatan Jual Beli Satuan Rumah Susun (“Kepmenpera No. 11/1994”). Dengan diberlakukannya Kepmenpera No. 11 Tahun 1994 tersebut, maka setiap adanya perikatan jual beli satuan rumah susun wajib mengikuti pedoman yang ditetapkan dalam Kepmenpera No. 11 Tahun 1994 tersebut. $^{3}$

Selain mengacu pada Kemenpera diatas apakah sudah ada regulasi yang secara spesifik mengatur mengenai transaksi jual beli Rumah Susun/Apartemen untuk Daerah Istimewa Yogyakarta Pasal 6 Peraturan Bupati Kabupaten Sleman Nomor 40 Tahun 2015 tentang Pengesahan, Pertelaan dan Akta Pemisahan

${ }^{2}$ Andrian Sutedi, Hukum Rumah Susun dan Apartemen, Sinar Grafika, Jakarta, 2010, hlm. 3.

${ }_{3}^{3}$ Helen Taurusia SH, http://www.hukumproperti.com/2010/12/14/pedoman-perikatan-jual-belisatuan-rumah-susun-berdasarkan-kepmenpera-nomor-11-tahun-1994/, diakses 26 Agustus 2015. 
Rumah Susun menyatakan bahwa, "proses jual beli Satuan Rumah Susun sebelum pembangunan Rumah Susun selesai dapat dilakukan melalui perjanjian jual beli yang dibuat dalam bentuk akta nota riil, sedangkan untuk kota Yogyakarta belum ada peraturan walikota mengenai pedoman transaksi jual beli Rumah Susun/Apartemen. Untuk melakukan transaksi penjualan dan pembelian Rusun/Apartemen dimaksud biasanya pengembang menggunakan jasa NotarisPPAT, Apakah Notaris-PPAT sekedar memberikan legalisasi saja atau meresmikan dalam bentuk akta otentik atas hubungan hukum transaksi jual beli Rusun/Apartemen, termasuk di dalamnya memberikan konsultasi hukum atas apa yang diperlukan para subjek hukum yang bertransaksi Rusun/Apartemen yang memerlukan jasa notaris.

\section{Rumusan Masalah}

Dari latar belakang tersebut masalah yang dapat dirumuskan dalam penelitian ini adalah: pertama, apakah sudah ada kesesuaian regulasi transaksi jual beli Rumah Susun/Apartemen di Daerah Istimewa Yogyakarta? Kedua, bagaimana seharusnya Notaris-PPAT berperan dalam hubungan hukum transaksi jual beli Rumah Susun/Apartemen di Daerah Istimewa Yogyakarta?

\section{Tujuan Penelitian}

Penelitian ini bertujuan untuk, pertama, menemukan apakah dari aspek hukum sudah ada kesesuaian regulasi transaksi jual beli Rumah Susun/Apartemen di Daerah Istimewa Yogyakarta. Kedua, untuk mencermati bagaimana seorang Notaris-PPAT seharusnya menjalankan perannya secara profesional berkenaan dengan transasksi jual beli Rumah Susun/Apartemen di Daerah Istimewa Yogyakarta. 


\section{Metode Penelitian}

Penelitian ini merupakan penelitian hukum normatif yang dilakukan dengan cara meneliti bahan pustaka ${ }^{4}$ yang bersumber dari data sekunder/data yang sudah tersedia. ${ }^{5}$ Berupa bahan hukum yang terdiri dari Peraturan Perundang-undangan Rumah Susun antara lain : UU Nomor 1 Tahun 2011 tentang Perumahan dan Kawasan Pemukiman, UU Nomor 20 Tahun 2011 tentang Rumah Susun, Peraturan Pemerintah Nomor 4 Tahun 1998 tentang Rumah Susun, Peraturan Menteri Perumahan/Kepmenpera Nomor 11/KPTS/1994 tentang Pedoman Perjanjian Perikatan Jual Beli Satuan Rumah Susun, Permendagri 32/2010 tentang Pedoman Pemberian Izin Mendirikan Bangunan, UU Nomor 30 Tahun 2004 Jo. UU Nomor 2 Tahun 2014 (tentang Jabatan Notaris), buku-buku, jurnal, artikel dan literatur lain yang berkenaan dengan permasalahan yang dibahas dengan pendekatan yuridis normatif, sedang pengolahan dan analisa data secara deskriptif-kualitatif.

\section{Hasil Penelitian dan Pembahasan}

\section{Aturan/Regulasi}

Peraturan perundang-undangan yang mengatur mengenai rumah susun dapat dicermati baik dari Undang-Undang, Peraturan Pemerintah maupun Peraturan Menteri sebagai berikut yaitu: Undang-Undang Nomor 16 Tahun 1985 Jo. Undang-Undang Nomor 20/2011 tentang Rumah Susun, Undang-Undang Nomor 38 Tahun 2008 tentang Bangunan Gedung, dan Undang-Undang Nomor 1 Tahun 2011 tentang Perumahan dan Kawasan Pemukiman. Dalam Peraturan Pemerintah ada pada: Peraturan Pemerintah 4 Tahun 1988 tentang Rumah Susun, Peraturan Pemerintah 40 Tahun 1996 tentang HGU, HGB dan Hak Pakai atas Tanah, Peraturan Pemerintah 36 Tahun 2005 tentang Peraturan Pelaksana 
Undang-Undang Bangunan Gedung. Sedangkan Peraturan Menteri berkenaan dengan Rumah Susun tersebut bisa ditemukan pada:

1. Kementrian Pekerjaan Umum (PU)

a. Permen PU No. 60/PRT/1992 tentang Persyaratan Teknis Pembangunan Rumah Susun

b. Permen PU No. 30/PRT/2006 tentang Pedoman Teknis Fasilitas dan Aksebilitas Pada Bangunan Gedung dan Lingkungan

c. Permen PU No. 05/PRT/M/2007 tentang Pedoman Teknis Pembangunan Rumah Susun Sederhana Bertingkat Tinggi.

2. Kementrian Perumahan

a. Permenpera Nomor 15/PERMEN/M/2007, tentang Tata Laksana Pembentukan PPPSRS.

b. Kepmenpera Nomor 11/KPTS/BPK4N/1994, tentang Pedoman Perikatan Jual Beli Satuan Rumah Susun.

c. Kepmenpera Nomor 06/KPTS/BPK4N/1995, tentang Pedoman Pembuatan Akta Pendirian AD/ART PPPSRS.

3. Kementrian Keuangan

a. PMKRI No. 103/PMK.03/2009, tentang Perubahan Ketiga atas Peraturan Menteri Keuangan Nomor 620/PMK.03/2004, tentang Jenis Barang Kena Pajak Yang Tergolong Mewah Selain Kendaraan Bermotor Yang Dikenakan Pajak Penjualan Atas Barang Mewah.

b. PMK RI no. 113/PMK.03/ 2014 (tentang Rusun Tidak Kena PPN)

c. SE Dirjen Pajak - 01/PJ.33/1998 tentang Perlakuan Perpajakan Bagi Pernimpunan Penghuni Dari Rumah Susun Yang "STRATA TITLE"

4. Kementrian Dalam Negeri

a. Permendagri Nomor 32/2010 tentang Pedoman Pemberian Izin Mendirikan Bangunan.

b. Permendagri Nomor 3 Tahun 1992 tentang Pedoman Penyusunan Peraturan Daerah Rumah Susun

c. Permendagri Nomor 74 Tahun 2007 tentang Pedoman Pemberian Kemudahan Perizinan dan Insentif Dalam Pembangunan Rumah Susun Sederhana Di Kawasan Perkotaan.

d. Permendagri Nomor 9 Tahun 2009 tentang Pedoman Penyerahan Prasarana, Saran dan Utilitas Perumahan dan Pemukiman di Daerah.

5. BPN (Kementriaan Agraria dan Tata Ruang)

a. Perkaban Nomor 2 Tahun 1989 tentang Bentuk dan Tata Cara Pengisian Serta Pendaftaran Akta Pemisahan Rumah Susun.

b. Perkaban Nomor 4 Tahun 1989 tentang Bentuk dan Tata Cara Pembuatan Buku Tanah Serta penerbitan SHMSRS.

Berkenaan dengan regulasi yang ada di Kota Yogyakarta dan Kabupaten Sleman baru saja diatur dengan Peraturan Wali Kota Nomor 7 Tahun 2015 Tentang Sertifikat Laik Fungsi Rumah Susun (dasar hukum pembentukannya untuk melaksanakan ketentuan Pasal 78 Peraturan Daerah Kota Yogyakarta 
Nomor 2 Tahun 2012 tentang Bangunan Gedung), Peraturan Wali Kota Nomor 8 Tahun 2015 tentang Pengesahan Akta Pemisahan Rumah Susun (dasar hukum pembentukannya untuk memberikan jaminan kepastian hukum atas pemilikan satuan-satuan rumah susun mengenai pengesahan akta pemisahan rumah susun), Peraturan Wali Kota Nomor 9 Tahun 2015 tentang Perhimpunan Pemilik dan Penghuni Satuan Rumah Susun tertanggal 27 Februari 2015 (dasar hukum pembentukannya bahwa dalam pengelolaan rumah susun perlu diatur pembentukan kelembagaan, hak suara, penunjukan pengelola, dan penyusunan anggaran dasar dan anggaran rumah tangga perhimpunan pemilik dan penghuni satuan rumah susun) dan Peraturan Bupati Sleman Nomor 40 Tahun 2015 tentang Pengesahan Pertelaan dan Akta Pemisahan Rumah Susun tertanggal 15 Juli 2015 (dasar hukum pembentukannya adalah agar pelaksanaan pengesahan pertelaan dan pemisahan rumah susun berjalan lancer dan efektif, dan bahwa berdasarkan ketentuan Pasal 26 ayat (4) dan Pasal 30 Undang Undang Nomor 20 Tahun 2011 tentang Rumah Susun, gambar dan uraian pemisahan rumah susun dituangkan dalam bentuk akta pemisahan yang disahkan oleh Bupati). Peraturan secara spesifik mengenai pedoman transaksi jual beli Rumah Susun/ Apartemen belum ada termasuk peraturan daerahnya, sedangkan di Kabupaten Sleman baru disahkan tanggal 15 Juli 2015 dengan Peraturan Bupati No. 40 Tahun 2015 tentang Pertelaan dan Akta Pemisahan Rumah Susun, yang dalam Peraturan Bupati ini hanya ada satu pasal yang mengatur jual beli Satuan Rumah Susun yang belum selesai di bangun. (Pasal 6 Peraturan Bupati Sleman Nomor 40 Tahun 2015 tentang Pengesahan Pertelaan dan Akta Pemisahan Rumah Susun).

Berdasar Pasal 17 Undang-Undang Nomor 20 Tahun 2011, rumah susun hanya dapat dibangun di atas tanah hak milik, hak guna bangunan atau hak pakai atas tanah negara dan hak guna bangunan diatas hak pengelolaan. Satuan rumah susun dapat dimiliki baik oleh perseorangan maupun badan hukum yang memenuhi persyaratan sebagai pemegang hak atas tanah, dan untuk mencapai tertib administrasi pertanahan serta memberikan kepastian dan perlindungan hukum kepada pemilik hak atas satuan rumah susun, maka sebagai tanda bukti kepemilikan pemerintah memberikan alat pembuktian yang kuat berupa 
sertipikat HMSRS (Hak Milik atas Satuan Rumah Susun) yang diterbitkan oleh Kantor Pertanahan Kabupaten/Kota setempat.

\section{Asas dan Tujuan Pembangunan Rumah Susun}

Perumahan dan pemukiman merupakan kebutuhan dasar setiap manusia. Dengan semakin bertambahnya penduduk, sedangkan lahan yang tersedia sangat terbatas, maka pembangunan rumah dibuat bertingkat atau yang kita kenal dengan rumah susun. Pembangunan rumah susun merupakan salah satu alternatif pemecahan masalah kebutuhan perumahan dan pemukiman terutama di daerah perkotaan yang jumlah penduduknya terus meningkat, karena pembangunan rumah susun dapat mengurangi penggunaan tanah, membuat ruang-ruang terbuka kota yang lebih lega dan dapat digunakan sebagai suatu cara untuk peremajaan kota bagi daerah yang kumuh.

Pembangunan rumah susun berlandaskan pada asas kesejahteraan umum, keadilan dan pemerataan, serta keserasian dan keseimbangan dalam perikehidupan. Asas kesejahteraan umum dipergunakan sebagai landasan pembangunan rumah susun dengan maksud untuk mewujudkan kesejahteraan lahir dan batin bagi seluruh rakyat Indonesia secara adil dan merata berdasarkan Pancasila dan Undang-Undang Dasar Negara Republik Indonesia Tahun 1945 melalui pemenuhan kebutuhan akan perumahan sebagai kebutuhan dasar bagi setiap warga negara Indonesia dan keluarganya.Asas keadilan dan pemerataan memberikan landasan agar pembangunan rumah susun dapat dinikmati secara merata, dan tiap-tiap warga negara dapat menikmati hasil-hasil pembangunan perumahan yang layak. Asas keserasian dan keseimbangan dalam perikehidupan mewajibkan adanya keserasian dan keseimbangan antara kepentingankepentingan dalam pemanfaatan rumah susun, untuk mencegah timbulnya kesenjangan-kesenjangan sosial. ${ }^{6}$ Asas-Asas Pembangunan Rumah Susun sebagaimana diatur dalam Pasal 2 Undang-Undang No. 20 Tahun 2011 dan penjelasannya menyatakan bahwa asas penyelenggaraan rumah susun adalah sebagai berikut: asas kesejahteraan, asas keadilan dan pemerataan, asas

${ }^{6}$ Adrian Sutedi, Hukum Rumah Susun dan Apartemen, Sinar Grafika, 2010, hlm 157. 
kenasionalan, asas keterjangkauan dan kemudahan, asas keefisienan dan kemanfaatan, asas kemandirian dan kebersamaan, asas kemitraan, asas keserasian dan keseimbangan, asas keterpaduan, asas kesehatan, asas kelestarian dan keberlanjutan, asas keselamatan, kenyamanan, dan kemudahan, serta asas keamanan, ketertiban, dan keteraturan

Tujuan pembangunan rumah susun seperti yang tercantum dalam Pasal 3 Undang-Undang Nomor 20 Tahun 2011 tentang Rumah Susun ialah: (a) Menjamin terwujudnya rumah susun yang layak huni dan terjangkau dalam lingkungan yang sehat, aman, harmonis, dan berkelanjutan serta menciptakan pemukiman yang terpadu guna membangun ketahanan ekonomi, sosial dan budaya; (b) Meningkatkan efisiensi dan efektivitas pemanfaatan ruang dan tanah, serta menyediakan ruang terbuka hijau di kawasan perkotaan dalam menciptakan kawasan permukiman yang lengkap serta serasi dan seimbang dengan memperhatikan prinsip pembangunan berkelanjutan dan berwawasan lingkungan; (c) mengurangi luasan dan mencegah timbulnya perumahan dan permukiman kumuh; (d) mengarahkan pengembangan kawasan perkotaan yang serasi, seimbang, efisien, dan produktif; (e) memenuhi kebutuhan sosial dan ekonomi yang menunjang kehidupan penghuni dan masyarakat dengan tetap mengutamakan tujuan pemenuhan kebutuhan perumahan dan permukiman yang layak, terutama bagi MBR; (e) memberdayakan para pemangku kepentingan di bidang pembangunan rumah susun; (f) menjamin terpenuhinya kebutuhan rumah susun yang layak dan terjangkau, terutama bagi MBR dalam lingkungan yang sehat, aman, harmonis, dan berkelanjutan dalam suatu sistem tata kelola perumahan dan permukiman yang terpadu; dan (g) memberikan kepastian hukum dalam penyediaan, kepenghunian, pengelolaan, dan kepemilikan rumah susun.

Di dalam Penjelasan Umum Undang-Undang Nomor 20 Tahun 2011, penyelenggaraan rumah susun bertujuan untuk menjamin terwujudnya rumah susun yang layak huni dan terjangkau, meningkatkan efisiensi dan efektivitas pemanfaatan ruang, mengurangi luasan dan mencegah timbulnya perumahan dan permukiman kumuh, mengarahkan pengembangan kawasan perkotaan, memenuhi kebutuhan sosial dan ekonomi, memberdayakan para pemangku 
kepentingan, serta memberikan kepastian hukum dalam penyediaan, kepenghunian, pengelolaan, dan kepemilikan rumah susun. Pengaturan dalam undang-undang ini juga menunjukkan keberpihakan negara dalam memenuhi kebutuhan tempat tinggal yang terjangkau bagi MBR serta partisipasi masyarakat dalam penyelenggaraan rumah susun.

Pembangunan rumah susun memerlukan persyaratan-persyaratan teknis dan administratif yang lebih ketat. Untuk menjamin keselamatan bangunan, keamanan, dan ketenteraman serta ketertiban penghunian, dan keserasian dengan lingkungan sekitarnya, maka satuan rumah susun baru dapat dihuni setelah mendapat izin kelayakan (dengan Sertifikat Laik Fungsi) untuk dihuni dari Pemerintah Daerah yang bersangkutan sesuai dengan peraturan perundangundangan yang berlaku. Penghuni satuan rumah susun (Sarusun) tidak dapat menghindarkan diri atau melepaskan kebutuhannya untuk menggunakan bagian bersama, benda bersama, dan tanah bersama, karena secara keseluruhan merupakan kebutuhan fungsional yang saling melengkapi.

\section{Aspek Hukum Transaksi Jual Beli Rumah Susun/Apartemen}

Segala dan semua yang berkenaan dengan aspek hukum transaksi jual beli Rumah Susun/Apartemen itu selalu terkait dengan beberapa hal yang mendahului sebelum dilakukannya transaksi jual beli Rumah Susun/Apartemen tersebut, diantaranya adalah berkenaan dengan izin-izin dari pihak-pihak yang terlibat menurut Undang-Undang, untuk Daerah Istimewa Yogyakarta tentu melibatkan kepala daerah yaitu Bupati/Walikota dengan dinas-dinas di daerah seperti, Dinas Pekerjaan Umum/PU/Kimpraswil, bagian hukum, Badan Perencana Pembangunan Daerah/BAPPEDA, serta instansi lain yang terkait seperti Badan Pertanahan Nasional (BPN) dengan Kantor Pertanahannya, Balai Lingkungan Hidup (BLH) dan seterusnya yang memberikan dan mengatur berbagai perizinan baik itu mengenai perizinan lokasi (Advice Planning, Site Plan, Izin Prinsip) maupun perizinan pembangunan menyangkut AMDAL, IMB, serta perizinan utnuk penjualan termasuk di dalamnya NPWP, SIUP, TDP, HO, dan hal lain yang semestinya diikuti sesuai regulasi yang ada di Daerah Istimewa 
Yogyakarta, berdasarkan ketentuan Undang Undang Nomor 1 Tahun 2011 tentang Perumahan dan Kawasan Pemukiman, yang pada Pasal 39 undang undang tersebut mengatur tanggungjawab mengenai pembangunan rumah susun yang didelegasikan kepada Pemerintah Daerah, dimana berdasarkan Pasal 40 undang-undang tersebut dalam melaksanakan tanggungjawab seperti dimaksud Pasal 39 undang-undang di atas Pemerintah Daerah menugasi dan membentuk lembaga/badan yang menangani pembangunan rumah susun sesuai ketentuan perundangan. Berdasarkan Undang-Undang 20 Tahun 2011 tentang Rumas Susun pada Pasal 39 ayat (1) meyebutkan pelaku pembangunan wajib mengajukan permohonan sertifikat laik fungsi kepada Bupati/Walikota setelah menyelesaikan seluruh atau sebagian pembangunan rumah susun sepanjang tidak bertentangan dengan IMB, sehingga kewenangan untuk memberikan segala dan semua perijinan tentang hal dimaksud menjadi kewenangan Pemerintah Kota/Kabupaten (sebagaimana pula diatur dalam Pasal 1 ayat (6) Peraturan Pemerintah Nomor 4 Tahun 1988 tentang Rumah Susun jo Peraturan Wali Kota Nomor 7 Tahun 2015 tentang Sertifikat Laik Fungsi Rumah Susun, Peraturan Wali Kota Nomor 8 Tahun 2015 tentang Pengesahan Akta Pemisahan Rumah Susun, Peraturan Wali Kota Nomor 9 Tahun 2015 tentang Perhimpunan Pemilik dan Penghuni Satuan Rumah Susun dan Peraturan Bupati Sleman Nomor 40 Tahun 2015 tentang Pengesahan Pertelaan dan Akta Pemisahan Rumah Susun).

Pada acara seminar rumah susun yang diselenggarakan Forum Kajian dan Konsultasi Pertanahan (FK2P) beberapa waktu lalu di Jakarta, Maria S. W. Soemardjono melihat kerancuan dan masalah hukum baru dengan disahkannya Undang-Undang Nomor 20 Tahun 2011 tentang Rumah Susun. Kerancuan itu setidaknya ada 3, menurutnya, yaitu pertama meliputi masalah definisi tanah sewa untuk bangunan dalam konteks tanah bersama di dalam Pasal 1 angka 4. Kedua, yaitu konstruksi hukum pembangunan rumah susun di atas tanah berstatus barang milik negara (BMN) atau barang milik daerah (BMD). Sedangkan kerancuan ketiga adalah mengenai kompilasi hukum pembangunan rumah susun di atas tanah hak guna bangunan (HGB) atau hak pakai (HP) di atas tanah hak pengelolaan (HPL) dalam konteks UU Nomor 1 Tahun 2004 tentang Perbendaharaan Negara dan PP Nomor 6 Tahun 2006 tentang Pengelolaan BMN/ 
BMD dan perubahannya, yaitu PP Nomor 38t Tahun 2008. Salah satu kerancuan yang terjadi di dalam Pasal 1 adalah masalah definisi tanah sewa untuk bangunan dalam konteks tanah bersama. Menurut UU ini di Pasal 1 angka 4 disebutkan bahwa, "Tanah bersama adalah sebidang tanah hak atau tanah sewa untuk bangunan atas dasar hak bersama secara tidak terpisah yang di atasnya berdiri rumah susun dan ditetapkan batasnya dalam persyaratan izin mendirikan bangunan". Menurut Maria, UU tidak memberikan interprestasi otentik tentang definisi "tanah sewa untuk bangunan", tapi pengertian ini secara tidak langsung bisa dilihat di Pasal 18 sampai Pasal 22. Menurutnya, istilah "tanah sewa untuk bangunan" diperkenalkan karena adanya kebutuhan praktis saja, bukan didasarkan pada konsep yang ada. Maria melanjutkan, konsep "tanah sewa untuk bangunan" di UU ini jelas tidak dimaksudkan sebagai tanah "hak sewa untuk bangunan" (HSUB) seperti yang diatur selama ini di UUPA di Pasal 44. Sebab tanah sewa menurut UUPA ini hanya bisa terjadi di atas tanah hak milik dan belum ada peraturan pelaksanaannya. ${ }^{7}$

Maria mengingatkan agar masyarakat harus memahami adalah bahwa "tanah sewa untuk bangunan" dikaitkan dengan pengertian "tanah bersama" merupakan tanah bersama yang dapat dipunyai oleh pemegang atau pemilik hak milik satuan rumah susun (HMSRS) yang tanahnya berstatus hak milik, hak guna bangunan atau hak pakai. Artinya, menurutnya, rumah susun harus berdiri di atas "tanah hak". "Tanah hak" ini adalah tanah yang dilekati dengan hak atas tanah menurut UUUPA. ${ }^{8}$

Winanto Wiryomartani menyoroti masalah sertifikat hak miliki (SHM) satuan rumah susun sebagai tanda bukti kepemilikan atas satuan rumah susun di atas tanah hak milik (HM), hak guna bangunan (HGB), hak pakai (HP) di atas tanah negara, serta hak guna bangunan/ hak pakai di atas tanah pengelolaan (HPL). Menurut Pasal 17 butir C dalam UU ini disebutkan bahwa HBG/ HP di atastanah HPL sebaiknya di sertifikat disebut dengan jelas mengenai status HGB atau HP tersebut berdiri di atas tanah HPL. Sehingga masyarakat, termasuk bank, bisa tahu sejak awal status haknya jika akan memberikan kredit dengan agunan

\footnotetext{
${ }^{7}$ http://medianotaris.com/uu rumah susun baru notaris harus hatihati berita134.html, diakses 26 Agustus 2015.

${ }^{8}$ Ibid
} 
sertifikat hak rumah susun ini, yaitu HGB/HP rumah susun ini berdiri di atas tanah hak pengelolaan. Masalah ini harus dijelaskan karena setiap pengalihan atau pembebanan hak tanah seperti ini harus seijin pemegang hak pengelolaan. ${ }^{9}$

Selain masalah sertifikat hak ini, Winanto juga mengingatkan agar dibuat suatu model akta pemisahan yang bersifat baku untuk bagian-bagian rumah susun. Dalam masalah bagian-bagian rumah susun itu, menurut Pasal 25 UndangUndang Nomor 20 Tahun 2011 diatur bahwa pelaku pembangunan harus memisahkan rumah susun atau satuan rumah susun, bagian bersama, benda bersama, dan tanah bersama. Untuk pemisahan rumah susun, wajib dituangkan dalam bentuk gambar dan uraian, serta dituangkan dalam bentuk akta pemisahan yang disahkan Bupati atau Walikota, selain itu ada beberapa hal yang dikritisi oleh Winanto, misalnya dalam hal rumah susun dibangun di atas tanah sewa yang sebaiknya perjanjiannya dilakukan secara nota riil, untuk Kabupaten Sleman dan Kota Yogyakarta baru saja muncul peraturan Bupati dan Peraturan Walikota pada bulan Februari dan Juli 2015 dan juga masalah kewajiban notaris dalam membuat perjanjian pengikatan jual beli (PPJB) yang harus melalui persyaratanpersyaratan. ${ }^{10}$

Terhadap pembelian unit-unit Rumah Susun/Apartemen yang belakangan marak di Yogyakarta tentu tidak lepas dari adanya promosi besar-besaran yang dilakukan oleh pengembang baik melalui media cetak maupun elektronik serta media pameran pada mall-mall yang bertebaran di Yogyakarta. Masyarakat banyak yang tertarik pada gambar-gambar rancangan yang bagus-bagus menyerupai aslinya meskipun Rumah Susun/Apartemen tersebut belum dibangun sehingga terjadilah transaksi. Beberapa potensi permasalahan dari transaksi jual beli Rumah Susun/Apartemen itu dapat saja muncul jika dari aspek hukum masyarakat tidak/kurang memahami peraturan tentang transaksi jual beli Rumah Susun/Apartemen, sebagaimana diatur dalam Undang-Undang 20/2011 tentang Rumah Susun pada Pasal 42-44 mengenai Pemasaran dan Jual Beli Rumah Susun. Dimana pelaku pembangunan dapat melakukan pemasaran sebelum pembangunan Rumah Susun dilaksanakan, dalam hal tersebut pelaku 
pembangunan sekurang-kurangnya harus memiliki kepastian peruntukan ruang (harus ada keterangan rencana kota yang disetujui Pemerintah Daerah), kepastian hak atas tanah (ada sertipikatnya), kepastian status penguasaan Rumah Susun (antara SHMSRS dan SKGB harus ditunjukan berdasar PERTELAAN yang disahkan oleh Pemerintah Daerah). Perizinan pembangunan Rumah Susun (dengan Izin Mendirikan Bangunan) dan jaminan atas pembangunan Rumah Susun dari lembaga penjamin (bisa berupa surat dukungan dari bank/non bank) oleh karenanya jika pemasaran dilakukan sebelum pembangunan Rumah Susun dilaksanakan, segala sesuatu yang diperjanjikan oleh pelaku pembangunan/agen pemasaran mengikat sebagai Perjanjian Pengikatan Jual Beli /PPJB bagi para pihak.

Masyarakat perlu juga memahami proses transaksi dalam pembelian unit Rumah Susun/Apartemen yang diawali dengan perjanjian pemesanan, dilanjut dengan Perjanjian Perikatan Jual Beli/PPJB jika proses pembangunan sudah mencapai 20 \% (dihadapan Notaris) dan barulah Akta Jual Beli (AJB) dihadapan Pejabat Pembuat Akta Tanah (PPAT) jika bangunan sudah selesai serta sudah terbit Sertifikat Laik Fungsi, SHMSRS dan SKBG. Dalam transaksi jual beli Rumah Susun/Apartemen dapat juga masyarakat menggunakan fasilitas KPA/Kredit Pemilikan Apartemen dari lembaga pembiayaan/Bank, yang tentu saja memerlukan dan melibatkan Notaris-PPAT untuk realisasinya.

\section{Peran Notaris-PPAT dalam Transaksi Rumah Susun/Apartemen}

Jabatan Notaris lahir dari adanya kebutuhan masyarakat ${ }^{11}$ sejak zaman dahulu, oleh karenanya Notaris diangkat sebagai "Pejabat Umum" yang bertugas melayani masyarakat, yang menurut R. Soegondo Notodisoeryo, Notaris adalah Pejabat Umum openbare-ambtenaren, karena erat hubungannya dengan wewenang atau tugas dan kewajiban yang utama yaitu membuat akta-akta otentik, ${ }^{12}$ sedangkan Wawan Setiawan menyatakan bahwa "Pejabat Umum" adalah Organ Negara yang diperlengkapi dengan Kekuasaan Umum, berwenang menjalankan

\footnotetext{
2009, hlm. 50.

${ }^{11}$ Pengurus Pusat Ikatan Notaris Indonesia, Jati Diri Notaris Indonesia, PT. Gramedia Pustaka, Jakarta,

${ }^{12}$ R. Soegondo Notodisoeryo, Hukum Notariat di Indonesia Suatu Penjelasan, Raja Grafindo Persada, Jakarta, 1993, hlm. 42.
} 
sebagian dari Kekuasaan Negara untuk membuat alat bukti tertulis dan otentik dalam bidang hukum perdata. ${ }^{13}$

Undang-Undang Nomor 30 Tahun 2004 Jo Undang-Undang Nomor 2 Tahun 2014 tentang Jabatan Notaris dalam Pasal 1 angka 1 memberikan definisi sebagai berikut "Notaris adalah pejabat umum yang berwenang membuat akta otentik dan kewenangan lainnya sebagaimana dimaksud dalam Undang-Undang ini. Kewenangan sebagaimana dimiliki seorang Notaris harus seiring dengan dan terbatas dengan kewajiban-kewajiban dan larangan sebagaimana diatur dalam Undang-Undang Jabatan Notaris tersebut. Hal yang berkenaan dengan transaksi jual beli Rumah Susun/Apartemen seorang Notaris dapat membuat Perjanjian Perikatan Jual Beli (PPJB) baik secara otentik maupun di bawah tangan dengan cara legalisasi, tergantung regulasi di daerah untuk Perjanjian Pengikatan Jual Beli (PPJB) Rumah Susun/Apartemen antara pembeli dan penjual (pengembang) apakah diharuskan secara otentik/nota riil ataukah dimungkinkan untuk dibuat secara di bawah tangan dengan legalisasi dari seorang Notaris, sedangkan untuk pembebanan dan peralihan hak atas Satuan Rumah Susun/Apartemen menjadi kewenangan Pejabat Pembuat Akta Tanah (PPAT) untuk membuatnya (Pasal 3 ayat (1) Peraturan Pemerintah Nomor 37 Tahun 1998 tentang Peraturan Jabatan Pejabat Pembuat akta Tanah).

Pelayanan jasa Notaris-PPAT sebagai bagian dari pelaksanaan pelayanan terhadap masyarakat harus berjalan sejajar dengan perkembangan masyarakat ke depan, kecermatan, kecepatan, dan kecakapan Notaris tidak hanya semata-mata berlandaskan pada sikap pandang yang bersifat formalistik akan tetapi harus berlandaskan pada sikap pandang yang profesionalistik sehingga usaha untuk meningkatkan mutu pelayanan Notaris benar-benar membawa hasil yang positif bagi masyarakat, ${ }^{14}$ sehingga seorang Notaris-PPAT sebagai pejabat umum harus mempertanggungjawabkan baik secara formil maupun moral, meskipun dalam penjelasan Undang-Undang Jabatan Notaris dinyatakan bahwa Notaris hanya bertanggungjawab terhadap formalitas dari akta otentik dan tidak terhadap

\footnotetext{
13 Wawan Setiawan, Kedudukan dan Keberadaan Pejabat Umum serta PPAT dibandingkan dengan kedudukan Pejabat Tata Usaha Negara menurut sistem hukum Nasional, Jakarta, 2 Juli 2001, hlm. 8, PP. IPPAT (Ikatan Pejabat Pembuat Akta Tanah).

14 Grace Giovani, Notaris, Kedudukan, Fungsi dan Peranannya, http://www.notarisgracegiovani.com/ artikelnotariat.html/, diakses 2 september 2015.
} 
materi akta otentik tersebut, namun Notaris diwajibkan untuk bersikap netral dan tidak memihak serta memberikan semacam nasehat hukum bagi klien yang meminta petunjuk hukum pada Notaris yang bersangkutan, sehingga dan karenannya secara morilpun Notaris dapat dipertanggungjawabkan atas kebenaran materiil suatu akta bila nasehat hukum yang diberikan ternyata dikemudian hari merupakan sesuatu yang keliru, melalui konstruksi penjelasan Undang Undang Jabatan Notaris tersebut dapat ditarik kesimpulan bahwa Notaris dapat pula diminta pertanggungjawaban atas kebenaran materiil suatu akta yang dibuatnya bila ternyata Notaris tersebut tidak memberikan akses mengenai suatu hukum tertentu yang berkaitan dengan akta yang dibuatnya sehingga salah satu pihak merasa tertipu atas ketidaktahuannya. Untuk itulah disarankan bagi Notaris untuk memberikan informasi hukum yang penting (necessary) yang selayaknya diketahui klien sepanjang yang berurusan dengan masalah hukum. ${ }^{15}$

Seorang Notaris seharusnya dan semestinya memberikan edukasi kepada subjek yang hendak bertransaksi jual beli rumah susun/Apatertmen dan menekankan betapa pentingnya sebelum dilakukan transaksi tersebut harus ada pertelaan dengan adanya sertifikat laik fungsi rumah susun. PERTELAAN di sini adalah daftar perincian tentang sesuatu hal berisi penjelasan tentang uraian, gambar dan batas secara jelas baik vertikal maupun horizontal dari masingmasing satuan rumah susun, bagian bersama, benda bersama dan tanah bersama beserta uraian nilai perbandingan proporsional (Pasal 1 (10) Peraturan Walikota Yogyakarta Nomor 7 Tahun 2015 tentang Sertifikat Laik Fungsi Rumah Susun) Notaris-PPAT harus memberikan pemahaman kepada para subjek yang bertransaksi mengenai segala dan semua yang terurai dalam "PERTELAAN" sehingga dengan demikian potensi masalah karena adanya kesesatan informasi dapat diminimalisir.

Subjek yang melakukan transaksi jual beli Rumah Susun/Apartemen harus mengerti bahwa jika dalam persyaratan izin mendirikan bangunan harus secara rinci menegaskan mengenai sebidang tanah hak atau tanah sewa untuk bangunan yang digunakan untuk dasar hak bersama secara tidak terpisah yang diatasnya

${ }^{15}$ Abdul Ghofur Anshori, Lembaga Kenotariatan Indonesia, UII Press, Yogyakarta, 2009, hlm. 38. 
berdiri Rumah Susun dan ditetapkan batasnya sebagai Tanah Bersama, sementara "Bagian Bersama" merupakan bagian rumah susun yang dimiliki secara tidak terpisah untuk pemakaian bersama dalam kesatuan fungsi dengan satuan-satuan rumah susun, misal lift, selasar, kolom, balok, ruang antara platform dan lantai atas. Demikian juga tentang Benda Bersama yang bukan merupakan bagian rumah susun melainkan bagian yang dimiliki secara bersama yang tidak terpisah untuk pemilikan bersama, misal pagar lingkungan, pos jaga, tempat parkir, dan juga taman, fasilitas olahraga yang kesemuanya berada di atas Tanah Bersama. Untuk Nilai Perbandingan Proporsional (NPP) merupakan angka yang menunjukan perbandingan antara satuan rumah susun terhadap hak atas bagian bersama, dan tanah bersama yang dihitung berdasarkan nilai sarusun yang bersangkutan terhadap jumlah nilai rumah susun secara keseluruhan pada waktu pelaku pembangunan pertamakali memperhitungkan biaya pembangunannya secara keseluruhan untuk menentukan harga jualnya. Untuk akta pemisahan yang merupakan tanda bukti pemisahan rumah susun atau satuan rumah susun, bagian bersama, benda bersama dan tanah bersama dengan pertelaan yang jelas dalam arah vertikal dan horisontal yang mengandung nilai perbandingan proporsional harus dibuat oleh pengembang yang harus disyahkan oleh pemda Kabupaten/Kota.

Adanya akta pemisahan yang telah disahkan Pemda Kabupaten/Kota maka akan muncul SHSMRS (Sertipikat Hak Milik Sarusun) yang merupakan tanda bukti kepemilikan sarusun di atas tanah negara, serta Hak Guna Bangunan atau hak pakai di atas tanah pengelolaan, serta SKGB (Sertipikat Kepemilikan Bangunan Gedung) yang merupakan tanda bukti kepemilikan atau sarusun di atas barangmilik negara/daerah berupa tanah atau tanah wakaf dengan cara sewa, SHMSRS (diterbitkan oleh Kantor Pertanahan Kabupaten/Kota, tercantum didalam Pasal 47 Undang-Undang Nomor 20 Tahun 2011 tentang Rumah Susun) dan SKBG (diterbitkan oleh instansi teknis Kabupaten/Kota yang bertugas dan bertanggungjawab di bidang bangunan gedung, tercantum di dalam Pasal 48 Undang-Undang Nomor 20 Tahun 2011 tentang Rumah Susun). Oleh karena itu, Notaris dan PPAT selayaknya mencermati alur perizinan berdasarkan undangundang baik itu dari sisi perizinan/pengadaan lokasi, perizinan pembangunan, 
dan perizinan pejualan, dimana proses pembangunan rumah susun, proses serah terima, dan proses operasionalnya merupakan hal yang harus diikuti dan dijadikan persyaratan oleh seorang Notaris jika akan meresmikan PPJB kepada konsumen/pembeli/enduser.

Karena terdapat hal-hal baru di dalam Undang-Undang Nomor 20 Tahun 2011 tentang Rumah Susun, pada Pasal 42 undang-undang ini mengatur mengenai pemasaran dan jual beli Rumah Susun bahwa (1) pelaku pembangunan dapat melakukan pemassaran sebelum pembangunan rumah susun dilaksanakan. (2) dalam hal pemasaran dilakukan sebelum pembangunan rumah susun, pelaku pembangunan sekurang-kurangnya harus memiliki; kepastian peruntukan ruang, kepastian hak atas tanah, kepastian penguasaan rumah susun, perizinan pembangunan rumah susun dan jaminan atas pembangunan rumah susun dari lembaga penjamin. (3) dalam hal pemasaran dilakukan sebelum pembangunan rumah susun segala sesuatu yang dijanjikan oleh pelaku pembangunan dan/atau agen pemasaran mengikat sebagai perjanjian pengikatan jual beli (PPJB) bagi para pihak, dengan demikian diharapkan para Notaris-PPAT di DIY hendaknya berhati-hati dan cermat dengan mempelajari baik-baik UU ini beserta peraturan terkait agar tidak keliru dan fatal akibatnya. Di dalam UU ini para Notaris dituntut cermat dan hati-hati agar nantinya tidak dibawa-bawa bila dalam proses peralihan hak atas rumah susun yang ditanganinya ternyata bermasalah sebagai akibat kekurangtahuan Notaris tentang aturan baru ini. Misalnya, kata Winanto, dalam melaksanakan PPJB, Notaris harus tahu betul masalah status kepemilikan tanah rumah susun, IMB-nya, ketersediaan, sarana, prasarana dan utilitas umum, dan juga masalah syarat keterbangunan sedikitnya 20 persen seperti yang diperintahkan UU. Bila ternyata nantinya timbul masalah hukum, dan ini disebabkan karena kekurangtahuan Notaris dalam masalah persyaratan ini maka akan menjadi masalah besar baginya. ${ }^{16}$ Notaris dan PPAT juga harus mencermati apakah dokumen-dokumen rusun yang akan di formulasikan dalam PPJB maupun AJB sudah ada atau belum, misalnya Gambar Pertelaan, SK. Akta pemisahan, SHMSRS, AD/ART PPPSRS, SK.PPPSRS dll. Mengingat UndangUndang dan Peraturan Pemerintah memberikan kewenangan kepada Pemda 
untuk mengatur secara detil berbagai perizinan yang ditetapkan oleh UndangUndang dan Peraturan Pemerintah yang pelaksanaannya harus diatur dalam Peraturan Daerah.

Berdasarkan Peraturan Pemerintah 38 Tahun 2007 tentang Pembagian Urusan Pemerintahan Antara Pemerintah, Pemda Provinsi dan Pemda yang telah di ubah dengan Undang-Undang Nomor 23 Tahun 2014 tentang Pemerintah Daerah yang menyebutkan bahwa urusan perumahan merupakan urusan wajib bagi permerintah daerah. Dengan diundangkannya Peraturan Pemerintah Nomor 4/1988 tentang Rumah Susun, sangat jelas bahwa pengaturan Rumah Susun di daerah menjadi kewenangan Daerah untuk mengaturnya, guna penerbitan sertifikat Hak Milik atas satuan rumah Susun ada beberapa persyaratan yang harus dipenuhi oleh penyelenggara pembangunan rumah susun/pengembang yang harus dimintakan kepada Pemerintah Daerah Kabupaten/Kota. (Pasal 5 dan Pasal 6 Peraturan Pemerintah Nomor 4 Tahun 1988 tentang Rumah Susun Jo Peraturan Wali Kota Nomor 7 Tahun 2015 tentang Sertifikat Laik Fungsi Rumah Susun, Peraturan Wali Kota Nomor 8 Tahun 2015 tentang Pengesahan Akta Pemisahan Rumah Susun, Peraturan Wali Kota Nomor 9 Tahun 2015 tentang Perhimpunan Pemilik dan Penghuni Satuan Rumah Susun dan Peraturan Bupati Sleman Nomor 40 Tahun 2015 tentang Pengesahan Pertelaan dan Akta Pemisahan Rumah Susun).

Daerah Istimewa Yogyakarta belum mempunyai Peraturan Daerah mengenai Rumah Susun, namun Peraturan Walikota dan Peraturan Bupati baru ada pada bulan Februari dan Juli 2015 setidaknya dapat menjadi guide line dan mengatasi bermunculannya Rusun/Apartemen bahkan sudah dilakukan transaksi unit-unit sarusun meskipun pertelaan, Sertifikat Laik Fungsi, IMB dan lain-lain belum ada, tentu bagaimana caranya pengembang penyelenggara pembangunan rusun segera memenuhi persayaratan persyaratan sebagaimana diatur dalam Peraturan Walikota maupun Peraturan Bupati di DIY.

Peraturan tentang transaksi jual beli Rumah Susun/Apartemen sebelum pembangunan dilaksanakan dapat dilakukan dihadapan Notaris melalui PPJB yang berdasar Pasal 43 undang-undang Rumah Susun harus memenuhi ketentuan sebagai berikut: jika PPJB dibuat sebelum Rumah Susun di bangun 
dapat dibuat dihadapan Notaris setelah memenuhi persyaratan kepastian atas : Status kepemilikan tanah, kepemilikan IMB, tersedianya prasarana, sarana dan utilitas umum dan sudah dibangun paling sedikit $20 \%$ dari seluruh luasan lantai.

Terhadap transaksi Rumah Susun ada ketentuan larangan sebagaimana diatur pada Undang-Undang Nomor 20 Tahun 2011 Pasal 97 yang mengatur tentang setiap pelaku pembangunan rumah susun komersial dilarang mengingkari kewajiban untuk menyediakan rumah susun umum sekurangkurangnya $20 \%$ (dua puluh persen) dari total lulas lantai rumah susun komersial yang dibangun sebagaimana dimaksud dalam Pasal 16 ayat (2) dan Pasal 98 mengatur pelaku pembangunan dilarang membuat PPJB yang tidak sesuai dengan yang dipasarkan, atau sebelum memenuhi persyaratan kepastian sebagaimana dimaksud dalam Pasal 43 ayat (2). Sedangkan mengenai ketentuan pidananya diatur pada Pasal 109 yang menyatakan setiap pelaku pembangunan rumah susun komersial yang mengingkari kewajibannya untuk menyediakan rumah susun umum sekurang-kurangnya $20 \%$ (dua puluh persen) dari total luas lantai rumah susun komersial yang dibangun sebagaimana dimaksud dalam Pasal 97 dipidana dengan pidana penjara paling lama 2 (dua) tahun atau denda paling banyak Rp. 20.000.000.000 (dua puluh miliar rupiah) dan Pasal 110 yang menyebutkan pelaku pembangunan yang membuat PPJB yang tidak sesuai dengan yang dipasarkan, atau sebelum memenuhi persyaratan kepastian sebagaimana dimaksud dalam Pasal 43 ayat (2), sebagaimana dimaksud dalam Pasal 98, dipidana dengan pidana penjara paling lama 4 (empat) tahun atau denda paling banyak Rp. 4.000.000.000 (empat miliar rupiah).

Jadi, ketentuan-ketentuan di atas oleh pelaku pembangunan (developer) dapat dikenakan ancaman hukuman pidana penjara 4 tahun dan denda Rp. 4.000.000.000,00 serta hal yang diperjanjikan yaitu kondisi sarusun yang dibangun dan dijual kepada konsumen yang dipasarkan, termasuk melalui media promosi, antara lain lokasi rusun, bentuk sarusun, spesifikasi bangunan, harga sarusun, fasilitas lain serta waktu serah terima sarusun, sedangkan berdasarkan Pasal 44 UU Rusun untuk proses jual beli yang dilakukan setelah pembangunan Rumah Susun selesai (bila telah terbit sertifikat laik fungsi dan SHMSRS ata SKBG 
sarusun) dilakukan melalui Akta Jual Beli dihadapan PPAT (untuk SHMSRS) dan Notaris untuk SKBG sebagai bukti peralihan hak.

Berdasarkan Keputusan Menpera Nomor 11/KPPS/94 tentang Pedoman PPJB Sarusun meliputi: 1. penandatangan surat pemesanan yang berisi nomor bangunan sarusun yang dipesan, nomor lantai, tipe sarusun, luas sarusun, harga jual, ketentuan pembayaran uang muka, spesifikiasi bangunan, tanggal selesainya pembangunan dan pernyataan setuju menerima persyaratan. 2. terhitung 30 hari kalender sejak tanggal surat pemesanan dilakukan penandatanganan akta PPJB (yang berdasarkan peraturan Walikota Yogyakarta dan Peraturan Bupati Sleman dilakukan di hadapan Notaris) yang memuat objek berikut fasilitas dilingkungan Rusun seseuai dengan NPP. 3. jual beli dilakukan dihadapan PPAT apabila telah terbit sertipikat Laik Fungsi, Sertipikat Hak Milik Sarusun, atau dihadapan Notaris untuk sertipikat SKBG (sertikat Kepemilikan Bangunan Gedung) berikut aturan pajak-pajak terkait rumah susun tersebut, yaitu untuk properti di atas Rp.42.000.000,- dikenakan Pajak Pertambahan Nilai (PPN) sebesar 10 \% dari harga jual untuk sarusun dengan harga bangunan per meter persegi di atas Rp. 4.000.000,- atau luasnya lebih dari $150 \mathrm{~m} 2$ dikenakan PPNBm (Pajak Pertambahan Nilai Barang Mewah) sebesar 20 \% dari harga jual (apabila dibeli dari developer), serta dikenakan BPHTB sebesar $5 \%$ (dari harga transaksi dikurangi harga jual objek pajak tidak kena pajak), untuk harga jual objek pajak tidak kena pajak dapat melihat dari Peraturan Daerah tentang BPHTB di masing-masing Pemerintah Daerah.Idealnya selama alur proses perijinan belum diikuti/belum dilaksanakan maka Notaris/PPAT belum bisa membuat akta-akta yang dimaksudkan sebagai transaksi jual beli rumah susun/apartemen dalam unit-unit sarusun untuk menghindari potensi masalah yang akan muncul.

\section{Penutup}

Bahwa pengaturan Rumah Susun/Apartemen di Daerah Istimewa Yogyakarta menjadi kewenangan daerah untuk mengaturnya. Penerbitan Sertipikat Hak Milik atas Satuan Rumah Susun/Apartemen dan transaksinya memerlukan beberapa persyaratan yang harus dipenuhi oleh 
pengembang/penyelenggara Rumah Susun/Apartemen yang harus dimintakan kepada Pemerintah daerah Kabupaten/Kota. Peraturan walikota Yogyakarta Nomor 7, 8 dan 9 baru disyahkan pada 27 Februari 2015 dan Peraturan Bupati Sleman Nomor 40 yang disyahkan 15 Juli 2015 masih merupakan pedoman yang seharusnya merupakan peraturan pelaksana yang harus bersesuaian dengan Peraturan Daerah yang mengatur tentang Rumah Susun/Apartemen yang belum ada saat ini di Daerah Istimewa Yogyakarta.

Berkenaan dengan peran, tugas, kewajiban dan kewenangan Notaris-PPAT terhadap transaksi Rumah Susun/Apartemen di Daerah Istimewa Yogyakarta, maka Notaris-PPAT harus menguasai semua dan segala regulasi mengenai Rumah Susun/Apartemen di Daerah Istimewa Yogyakarta, sehingga bisa berperan secara profesional menjadi konsultan hukum secara mendasar bagi masyarakat pengguna jasanya dan pada saat membuat akta-akta berkenaan dengan Rumah Susun/Apartemen dari sejak membuat perjanjian-perjanjian awal sampai dengan Akta Jual Beli (peralihan) serta pembebanan jika ada selalu dan harus memeriksa dan mencermati dari aspek legalitas baik dari sisi subyek maupun obyek sehingga ketika terformulasi kedalam suatu akta akan mempunyai otentisitas yang sempurna sebagai alat bukti dan meminimalisir potensi risiko hubungan hukum transaksi jual beli Rumah Susun/Apartemen dari masyarakat yang melakukannya.

Saran dari peneliti adalah sehubungan Peraturan Daerah mengenai Rumah Susun/Apartemen di Daerah Istimewa Yogyakarta belum ada maka perlu segera dibuat sebagai pengendali perkembangan banyaknya Rumah Susun/Apartemen di Daerah Istimewa Yogyakarta, dimana mengenai pedoman untuk transaksinya juga harus diatur baik dari sisi subjek pengembang, pembeli, maupun dari objeknya mengenai status hak, perizinan pengadaan lahan maupun perizinan penjualannya dengan memperhatikan dari aspek hukumnya, sehingga NotarisPPAT pun ketika menjalani perannya dalam transaksi jual beli Rumah Susun/Apartemen akan memberikan pemahaman kepada masyarakat yang menggunakan jasanya dengan dasar-dasar yang jelas sebagaimana dituangkan dalam Peraturan Daerah beserta aturan pelaksanaannya, baik itu peraturan Bupati/Wali Kota setempat. 


\section{Daftar Pustaka}

Anshori, Abdul Ghofur, Lembaga Kenotariatan Indonesia, Prespektif Hukum dan Etika, UIIPress,Yogyakarta, 2009.

Blaang, C. Djemabut, Perumahan Pemukiman sebagai kebutuhan Dasar, Yayasan Obor Indonesia, Jakarta, 1986.

Budiono, Herlien, SH, Ajaran Umum Hukum Perjanjian dan penerapannya di bidang Kenotariatan, PT. Citra Aditya, Bandung, 2009.

Fuad, Munir, Hukum Bisnis Dalam Teori dan Praktek, buku kedua, Citra Aditya Bakti, Bandung, 1996.

Kallo, Erwin,Panduan Hukum Untuk Pemilik/Penghuni Rumah Susun, Minerva Athena Pressindo, Jakarta, 2009.

Nico, Tanggungjawab Notaris Selaku Pejabat Umum, Center For Documentation and Studies of Business Law, Yogyakarta, 2003.

Notodisoerjo, Soegondo R., Hukum Notaris di Indonesia Suatu Penjelasan, Raja Grafindo Persada, Jakarta, 1993.

PP INI, Jati Diri Notaris Indonesia, PT. Gramedia Pustaka, Jakarta, 2009.

Setiawan, Wawan, Kedudukan dan Keberadaan Pejabat Umum serta PPAT dibandingkan dengan kedudukan Pejabat Tata Usaha Negara Menurut Sistem Hukum Nasional, PP IPPAT, 2001.

Soekanto, Soeryono, Pengantar Penelitian Hukum, cetakan ketiga, UII Press, Jakarta, 1984.

Soekanto, Soeryono dan Sri Mammudji, Penelitian Hukum Normatif, Pengantar Singkat, Rajawali Press, Jakarta, 1990.

Sutedi, Adrian, Hukum Rumah Susun dan Apartemen, Sinar Grafika, Jakarta, 2001.

Syaifurrachman, dan Habib Adjie, Aspek Pertanggungjawaban Notaris Dalam Pembuatan Akta, CV. Manda Maju, Bandung, 2011.

http: //www.hukumproperti.com/2010/12/14/pedoman-perikatan-jual-belisatuan-rumah-susun-berdasarkan-kepmenpera-nomor-11-tahun-1994/, diakses 26 Agustus 2015.

http://medianotaris.com/uu_rumah_susun_baru_notaris_harus_hatihati_berita1 34.html, diakses 26Agustus 2015.

http:/ / www.notarisgracegiovani.com/artikelnotariat.html/diakses september 2015

Republik Indonesia Undang-Undang Dasar Negara Republik Indonesia Tahun 1945.

Republik Indonesia Undang-Undang Nomor 16/1985tentang Rumah Susun.

Republik Indonesia Undang Undang Nomor 20/2011 tentang Rumah Susun. 
Republik Indonesia Undang-Undang Nomor1/2011 tentang Perumahan dan Kawasan Pemukiman.

Republik Indonesia Undang-Undang Nomor 30 Tahun 2004 tentang Jabatan Notaris.

Republik Indonesia Undang-Undang Nomor 2 Tahun 2014 tentang Jabatan Notaris.

Peraturan Pemerintah Nomor 4 Tahun 1998 tentang Rumah Susun.

Peraturan Menteri Dalam Negeri Nomor 32/2010 tentang Pemberian Izin Mendirikan Bangunan, untuk bangunan bertingkat disebut "Rumah Susun.

Peraturan Menteri Perumahan/Kepmenpera Nomor 11/KPTS/1994 tentang Pedoman Perjanjian Perikatan Jual Beli Satuan Rumah Susun.

Keputusan Menteri Negara Perumahan Rakyat Republik Indonesia Nomor 11/KPTS/1994 tahun 1994 tentang Pedoman Perikatan Jual Beli Satuan Rumah Susun.

Peraturan Bupati Sleman Nomor 40/2015 tentang Pengesahan, Pertelaan dan Akta Pemisahan Rumah Susun.

Peraturan Walikota Yogyakarta Nomor 7 tentang Sertifikat Laik Fungsi Rumah Susun.

Peraturan Walikota Yogyakarta Nomor 8 tentang Pengesahan Akta Pemisahan Rumah Susun

Peraturan Walikota YogyakartaNomor 9 tentang Perhimpunan Pemilik dan Penghuni Rumah Susun. 